Open Access

\title{
A review of the benefits and drawbacks to virtual field guides in today's Geoscience higher education environment
}

\author{
Anthony David Cliffe(D)
}

Correspondence:

A.D.Cliffe@2016.ljmu.ac.uk

Liverpool John Moores University, Faculty of Education, Health and Community, School of Education, I M Marsh Campus, Barkhill Road, Aigburth, Liverpool L17 6BD, UK

\begin{abstract}
Virtual Field Guides are a way for educators to tackle the growing issue of funding pressures in areas of higher education, such as geography. Virtual Field Guides are however underutilised and can offer students a different way of learning. Virtual Field Guides have many benefits to students, such as being more inclusive, building student skills and confidence in a controlled environment pre fieldtrip and can increase engagement in the topic studied. There are also benefits to the educator, such as reduced cost, more efficient students on fieldwork tasks and the ability to tailor and update their field guides to suit their needs. However there are drawbacks in the challenge of creation and their outcome as educational standalone tools. This paper reviews the literature around the benefits and draw backs to the creation and incorporation of virtual field guides in geoscience education.
\end{abstract}

Keywords: Virtual field guides, Fieldwork, Technology, Review, Geoscience

\section{Changing nature of fieldwork}

Fieldwork in Geoscience today has changed and developed due to the increase in technology and the need to keep up with the rapid pace of modern day life (Fuller, 2012). However, the pedagogical element of field courses has changed also, with a shift towards smaller numbers of students in groups investigating smaller scale problems that they can tackle (Simm \& David, 2002). While fieldwork is undoubtedly important, it does not make an effective teaching and learning method in its own right (Lonergran \& Andres, 1988). As detailed by Lonergran and Andres (1988), taking students into the field does not guarantee an enhanced learning experience. For this to occur, it must align to the curriculum of the course (Andrews, Kneale, Sougnez, Stewart, \& Stott, 2003). This provides the students with the opportunity to transfer learning from elements in the classroom to real world scenarios and helps develop their future understandings of topics to come (Biggs, 2003). There should be an emphasis placed on the preparation of debriefing students, both pre and post fieldtrip, to continually assess the effectiveness of students understanding of the link between the course materials and the fieldtrip (Kent, Gilbertson, \& Hunt, 1997). Students who carry out geoscience fieldwork indicate a 'geographical reality' while expressing more social benefits such as feelings of belonging to a group and increasing their interactions with peers and tutors (Fuller, Edmondson, France, Higgitt, \& Ratinen, 2006; Marvelf, Simm, Schaaf, \& Harpe, 2013).

(C) The Author(s). 2017 Open Access This article is distributed under the terms of the Creative Commons Attribution 4.0 International License (http://creativecommons.org/licenses/by/4.0/), which permits unrestricted use, distribution, and reproduction in any medium, provided you give appropriate credit to the original author(s) and the source, provide a link to the Creative Commons license, and indicate if changes were made. 
This geographical reality increases further when students partake in local based research. Studies by Rawlings (1981) and Garver (1992), have shown that during locally based studies, students have a better connection and understanding to their immediate environs. Due to this connection they tend to be more engaged and have a deeper understanding and appreciation for the need for fieldwork, while gaining an appreciation of the objective of the course compared to fieldwork carried out in a more distant and un-relatable landscape (McElroy, 1981; Slater, 1993; De Paor \& Whitmeyer, 2009; Israel, 2012).

\section{Fieldwork today}

Fieldwork and the fundamental pedagogic approaches have changed along with the different type of delivery of the courses (De Paor \& Whitmeyer, 2009). Today there has been a move away from the Cook's tour model of fieldwork towards a more inclusive, diverse, and holistic approach to learning in the field, aided by new technologies (McCaffrey, Jones, Holdsworth, Wilson, Clegg, et al., 2005).

With the introduction of low cost airlines in the early 2000's (Calder, 2003), ticket prices plummeted and locations for fieldwork became more accessible and more within budget (Fuller et al., 2006). For the first time university students now had the opportunity for fieldwork abroad that was not present before (Israel, 2012). With the introduction of the internet, ICT systems (ICT systems which include hardware, software and the people who use them) (Bowman et al., 2005) and more recently mobile technologies, the landscape of teaching in fieldwork has dramatically changed (Fuller \& France, 2014). It has been over 30 years since Gardiner and Unwin (1986), first used computer based technology in fieldwork to analyse results collected, which is a standard practice today. Now many students' possess mobile technologies which allows them to access data pre, post and during a fieldtrip (Welsh, Mauchline, Park, Whalley, \& France, 2013). Such data and information is far in excess of the data students would have had access to in the early days of Cook's Tour fieldtrips (Medzini, Meishar-Tal, \& Sneh, 2015). With the rapid expansion and development of new affordable technologies and ICT in fieldwork, has enabled students and tutors to become more efficient in the field (Martin \& Ertzberger, 2013). Technology such as mobile applications and handheld data collection devices e.g. tablet and handheld GPS have speeded up the data collection process (Wentzel, 2005). This means that fieldtrips can incorporate more learning objectives per trip than ever before (Welsh \& France, 2012). Mobile technologies have also allowed a different form of teaching to occur on fieldtrips through the use of collaborative data collection, off campus learning and student guidance via social media (Chen \& Huang, 2012).

Despite all of this new technology and its incorporation into today's fieldtrips, there is still an intrinsic pedagogical need for physical field trips. Nevertheless there has been a continued decline in the number of fieldtrips taken in the UK due to a number of reasons (Leydon \& Turner, 2013). Firstly, there has been a rapid increase in higher education student numbers in the UK (UK GOV, 2016) and Geoscience subjects continue to rise to record levels (Royal Geographical Association, 2016). This has placed enormous amounts of financial pressures on faculties along with staff time commitments to complete fieldwork (Welsh \& France, 2012). Such pressures have created a dilemma where some institutions are opting to pay for compulsory fieldwork, while offering many alternative or extra fieldwork at the cost of the student (Fletcher \& Dodds, 2004). 
This raises equitable concerns and places burdens on students who cannot financially afford such extracurricular activities (Fuller, Gaskin, \& Scott, 2003). Students at an unfair disadvantage are also brought to light through the need for fieldtrips to be inclusive of disabilities and differing needs of students and genders (Rose, 1993; Hall, Healey, \& Harrison, 2004). Technological advancements as mentioned previously have negated some of the need to leave the confines of the classroom, mainly through the introduction of GIS and video imagery (Fuller \& France, 2014). Due to this, alternatives are being sought to fieldwork such as the introduction of the virtual field trip.

\section{What is a virtual field guide?}

The development of the internet and tools available such as mobile technologies for students to access information, has rapidly increased in the previous decade (Kaplan \& Haenlein, 2010). Now more than ever is there a notion of collaborative rich data sets created online in communities from amateurs to professionals, for which both educators and students, can access to enhance their learning environments (Litherland \& Stott, 2012). Although, there is little argument in literature to deny the benefits of fieldwork, it does come with its challenges.

Virtual Field Guides (VFG), Virtual Field Trips or Virtual Fieldwork are terms used interchangeably throughout literature yet they are contested concepts with varying definitions (Litherland \& Stott, 2012). Virtual Field Trips in essence try to capture the real world environment of a specific location or region through a collection of data, photographs, cartography and other technologies such as GIS, without the cost of physically being there (Carmichael \& Tscholl, 2011). As argued by Stainfield, Fisher, Ford, and Solem (2000), the best examples of Virtual Field Trips are the ones which incorporates both old and new methods, yet allow participation and exploration of the environment and for students to develop the skills associated with those methods. E-learning, which is defined as "electronically mediated asynchronous and synchronous communication for the purpose of constructing and confirming knowledge" (Garrison, 2011, p. 2) have shown to increase learning through active participation rather than passive (Fletcher, France, Moore, \& Robinson, 2007). This model of learning is a key concept behind the educational benefits of using virtual field guides/trips in higher education teachings. It encourages the use of participation and engagement with the virtual environment with peers and tutors.

The aim of the Virtual Field Trip at present, has not been to replace the traditional fieldtrip but to introduce students to the fundamental skills needed to understand their environment before going on the 'real' fieldtrip (Gilmour, 1997). Due to the lack of "virtual" such as being immersed in a 3D augmented reality, the term Virtual Field Guide (VGF) will be used from here on, instead of virtual field trip.

VFG's are often a repository of various data, yet what makes them more than just this, is often an element of educator led discussion situated within a framework of tasks to be completed (Stott, Litherland, Carmichael, \& Nuttall, 2014). Some VFG's try to create an opportunity of travel for the students without ever leaving the confines of the classroom. For example Jacobson, Militello, and Baveye (2009), created a VFG were the course was broken down into days and stops with specific tasks to be completed at each one, much like a real fieldtrip. Older VFG's are more simplistic by just making 
available data such as photographs, maps or videos with tutor led commentary for students to get a feel for the environment (Baggott la Velle, 2005).

Spatial scale is of vital importance for geoscience disciplines and must be taken into account when considering VFGs (Jones, McCaffrey, Clegg, Wilson, Holliman, et al, 2009). The scale of virtual field guides often differ depending on their purpose and their aims (Ramasundaram, Grunwald, Mangeot, Comerford, \& Bliss, 2005). Spatial scale in VFGs can be small scale providing large overviews of topographical data such as mountain ranges (Stott, Nuttall, \& McCloskey, 2009; Eusden, Duvall, \& Bryant, 2012) and national parks (McMorrow, 2005). Small spatial scale VFG's can provide a student with a deeper understanding and situational awareness of the topic or location that they are studying (Jacobson et al., 2009). Often students do not maximise their time on fieldwork due to lacking the bigger conceptual picture (Falk, Martin, \& Balling, 1978). Providing a large overview of a field location helps a student to formulate ideas and apply knowledge to how that field site sits within the wider world. Small scale VFGs however lack finer details, for example in the VFG designed by Arrowsmith, Counihan, and McGreevy (2005) students anecdotally mentioned that they misinterpreted the distances between sites and that steepness of gradients were vastly under estimated.

Larger spatial scale virtual field guides provide the opposite in the sense that they are highly detailed and can vary from meters of a walking path, to a smaller section of cliff face (Pringle, Westerman, \& Gardiner, 2004). Larger scale VFGs are more practical as they replicate what would be seen if a student were to visit in reality (Jones et al., 2009). Details are more visible at this scale, with individual rocks and trees shown in high detail which allow students to explore and research in depth. At this scale it further facilitates students' skill development by practicing skills here that they may use on real field work which would be difficult with a smaller spatial scale VFG. However, larger scale VFGs are large in terms of data size due to their high detail and so when creating a VFG there must be a trade-off of scale and detail (Arrowsmith et al., 2005).

One issue with VFGS is their lack of standardisation. While there is no agreed spatial scale for VFGs due to their varying purpose and nature as commented on by Arrowsmith et al. (2005) multilayers of VFG scale that are all linked to each other provide the best learning experience for students. In their study they had a three scale approach that incorporated small to large spatial scales. The first VFG was a small scale overview of an entire park, the second was a larger spatial scale of the area that they would conduct most of their fieldwork and finally a large spatial scale that was a site specific VFG was developed with a geospatial link between all three 'nested' models.

\section{Benefits of virtual field guides}

Stainfield et al. (2000), stated that VFG in terms of material for actual fieldtrips have many benefits over traditional handbooks such as;

- Much easier to update VFG's year on year and with last minute changes

- Active links to different sources of all kinds from websites to videos

- No real size or capacity limits

- Cannot be physically lost on the field course

- Portable, especially on today's mobile technology 
One of the main benefits and reasons for the drive behind the creation and implementation of VFG's is their cost to outcome ratio. VFG's are significantly cheaper to develop and implement in a course than it is to take an actual physical fieldtrip (Jacobson et al., 2009). Today's higher education system is being squeezed for funding while resources such as staff time are being stretched. In addition, due to external pressures placed on faculties and staff time such as the Research Excellence Framework (REF), it is becoming harder to justify fieldtrips in faculty budgets, or at least to justify the number of fieldtrips taken per academic year (Krakowka, 2012). Therefore VFG's provide a potential alternative.

\section{Development of student skills and efficiency in the field}

Due to limited resources and time when on 'real' fieldwork, academic staff want to spend as much time as possible getting the most out of their environment for the students (Stoddard, 2009). VFGs therefore, permit introductory information about the field site to be learnt by the students before going to visit it for real (Spicer \& Stratford, 2001; Kingston, Eastwood, Jones, Johnson, Marshall, et al., 2012; Litherland \& Stott, 2012). As identified by Tuthill and Klemm (2002), combining VFGs with 'real' field work provides the students with prior knowledge of the site, what data they are tasked to collect, and how to analyse it and or have designed and developed their own projects before visiting the field site for real. VFGs not only include all students but they also allow them to develop their skills and enhance their confidence in implementing such skills, in a real world environment. Such confidence that can be developed before a real fieldtrip means a better quality learning and data collection process for the student which further enhances the benefits of real fieldwork (Killerman, 1996; Warburton \& Higgitt, 1997; Bellan \& Scheurman, 1998; Rozell \& Garner, 2000). VFGs 'supportive simulacra' allow an environment, to in essence, scaffold students in building their own understanding of the tasks set both pre and post real field visit by incorporating their own and secondary data. This is arguably the key area in which VFGs can be used as online learning tools in geosciences education (Litherland \& Stott, 2012).

Dykes (2000) evidenced a greater understanding and depth of knowledge in students via this dual approach and has encouraged the introduction of peer review and collaboration. Therefore when the students arrive at the field site they can get down to developing those skills in the field straight away, maximising their time for which Kent et al. (1997) stated makes successful graduates from the completion of real fieldwork.

Spicer and Stratford (2001) investigated how biology students felt about the use of a virtual field trip in relation to tide pools. Of their study, $80 \%$ of students showed a highly positive attitude towards the educational value of this VFG. Many students stated that the benefits of exploring an area before actually visiting, increased their confidence by being able to explore, make mistakes and allows them to use the materials and prior knowledge gained for their own virtual field note books to compare when in the field.

\section{Inclusivity and student engagement}

Although the cost element of fieldwork is more a faculty or departmental burden to deal with, students and specifically student engagement and inclusivity is a real issue 
that can be addressed by VFG's. Today's higher education environment allows and accommodates all different types of disabilities in students from the physically disabled to mental health issues (Seale, 2013). This inclusivity however is challenged when it comes to real fieldwork opportunities, especially in geoscience disciplines (Hall, Healey, \& Harrison, 2002). Geoscience disciplines often have a low number of disabled students due to the emphasis placed on undergraduate fieldwork and research. Fieldwork can prove to be a barrier for certain students due to the inaccessible nature of some field sites. There may also be a reluctance from organisers due to increased insurance costs (Atchison \& Feig, 2011). This leaves a student either being left out of that particular part of the trip or being advised not to attend at all (Hall et al., 2002). VFGs therefore eliminate the need for this inadvertent discrimination by reducing the need for physical travel. VFG's are incredibly accessible for students of all types and all abilities (Klemm \& Tuthill, 2003).

\section{Cost and other issues}

VFGs can potentially eliminate some of the issues that physical field trips can create. Traditional fieldtrips and principally those of an international nature have a number of disadvantages. The cost often means that not every student can afford to participate (many faculties ask students to fund at least part of the trip, with many now being optional) (Stokes, Collins, Maskall, Lea, Lunt, et al., 2012). There may be gendered issues, cultural and language barriers, logistical issues, security issues and problem in creating accurate risk assessments without prior visits by staff (Ternan, Charlkley, \& Elmes, 1999). There are also issues around privileged, educated, and relatively affluent university students going to view and study underprivileged groups or locations in poorer societies, often without their consent (Robinson, 1998).

\section{Seasonal change replication}

One of the few negatives of physical fieldwork is that the location is only visited first hand at that specific time and date. While for some locations and purposes of fieldwork sites this is not an issue, for others the landscape dramatically changes depending on the seasons. For example the flora and fauna differ depending on summer or winter seasons (Forman, 2014). Many other locations and the processes that govern that landscape change depending on the seasons. The benefit of VFGs and the quick and easy options to update the field guides, allows a student to visit these sites in all of those different seasons, vastly reducing the cost of travel and in some cases mitigating against extreme weather (Tuthill \& Klemm, 2002).

\section{Drawbacks of virtual field guides}

Some argue that VFGs cannot, and will not, replace the tried and tested method of real fieldwork (Arrowsmith et al., 2005). In contrast to the benefits of VFGs as stated by Spicer and Stratford (2001), when students were asked if they learnt more from an VFG and if a VFG should replace the traditional fieldtrip, they showed a significant disagreement to those statements $(P<0.001)$. They stated that although the VFG was useful it did not compare to the actual experience of a field trip. This was a similar notion discovered by Arrowsmith et al. (2005), whose students stated that VFGs do not 
provide the same experience or chance for students to develop the skills most developed on real world field trips such as team work and communication. 'Real' fieldwork exposes students to different environments by taking them out of their comfort zone, giving hands on practical experience which despite increasing technology such as augmented reality, as of yet, cannot replace this physically (Stainfield et al., 2000). Students on fieldwork often take away the experience of team work, bonding with fellow classmates and tutors, as one of the most successful parts of a fieldtrip (Dunphy \& Spellman, 2009). The difficulty that VFGs have in replacing traditional fieldwork is the intrinsic nature of fieldwork which is to get out and explore the world around them (Bellan \& Scheurman, 1998). While VFGs do allow for the exploration of sites, through data, maps and digital technologies they are not the same as visiting first hand (Hurst, 1998).

\section{Challenges of creation}

When completing VFGs, students can sometimes get disoriented within the virtual world and this hinders their ability to learn effectively (Stainfield et al., 2000; Spicer \& Stratford, 2001; Baggott la Velle, 2005; Garner \& Gallo, 2005). Although VFGs are relatively cheap compared to actual field trips, they are not a simple task to create (Bertol \& Foell, 1997). VFGs require technical expertise to create and make engaging, in a way that is beneficial to students (Ramasundaram et al., 2005). As outlined by Stott et al. (2009), the creation of VFGs can be challenging for tutors due to time pressures. Although an academic can retain complete control over the creation and updating of a VFG, limitations include time pressures from teaching and research. An academic is often unfamiliar with the software and requires extensive training which further increases the time spent on development. The creation of a VFG is stated to take approximately $50 \mathrm{~h}$ (Stott et al., 2009), which is similar to the completion time of an academic paper (Stott, Nuttall, Eden, Smith, \& Maxwell, 2008). Even when a dedicated technician is employed to look after the development of a VFG, Stott et al. (2009) voiced the frustration of having to wait for sites to be updated and issues arise when such technicians leave their post.

\section{Limitations of technology}

VFGs have been limited by technology and have struggled to expand due to a lack of computing power and memory, a real problem which often occurs when conducting a VFG with large class sizes (France, Whalley, Mauchline, Powell, Welsh, et al., 2016). Due to this, the issue of scale vs detail is one that the creator must finely balance with regards to the objectives of the VFG and computing power that is available. Often VFGs are currently web based and often accessed through module pages on a University system. While this increases the portability and accessibility nature of VFGs it further limits their detail. VFGs have often struggled to become virtual in the sense that the technology for immersion was lacking and often required cumbersome body suits to place the user in the computer generated field (Jacobson et al., 2009). Currently it is impractical and costly to suit students up in motion capture technology to physically walk in the virtual environment and there is yet to be a completely affordable technology that allows for a student to be fully immersed in this virtual world. So while 
VFGs are very interactive and can be highly detailed, the student still sees that environment via a computer screen which limits its virtual aspect and thus its comparison to a real field trip. A summary table of the benefits and drawbacks to VFGs can be found in Table 1 .

\section{Integration of future technology in future fieldwork and virtual fieldwork}

Traditional and virtual field trips have the potential to be greatly enhanced by the rapid introduction of new and affordable technologies (Brown \& Green, 2016). Such new technologies will further enrich the fieldwork environment and increases the efficiency of skill development (Whalley, France, Park, Mauchline, Powell, et al., 2015). Such new technologies are beginning to change the game of fieldwork again. As seen by the changing nature of fieldwork since the traditional Cook's Tour methods in the 1960's, it can be argued that in today's digital and technological age, fieldwork may well be entering a new phase of development (Wall \& Speake, 2012).

Technology is rapidly improving in both usability and affordability (King, 2011). Mobile technologies have been demonstrated to good effect in fieldwork through the use of podcasting, digital videos, remote sensing from tablets, geo-tagging and annotations (Jarvis \& Dickie, 2010; Fearnley \& Bunting, 2011; Welsh \& France, 2012). Fieldwork is starting to move beyond the traditonal methods of data collection in both the physical and human aspects of geoscience (Medzini et al., 2015). One such example of this is the long established method of recording observations through field sketches and field note books. These items are still important for today's students. Field sketches and note books allow students to analyse different aspects of the world around them by recording the scene, for which they can refer to such notes post fieldtrip (Kneale, 2014). Recording observations has often been completed on a physical paper note pad with a pencil, however times are changing. Technology such as digital cameras and mobile technologies such as portable smartphones and tablet computers, have given the traditonal field notebook a new look. Now, there is no need for a fieldsketch, instead a student can take a picture and annotate, draw and even include audio and video snippets, onto a single photograph (France et al., 2016). This enhances the learning for the student while making the whole process more efficient so that more

Table 1 Benefits and drawbacks to virtual field guides

\begin{tabular}{|c|c|}
\hline Benefits of virtual field guides & Drawbacks of virtual field guides \\
\hline Relatively cheap to create & $\begin{array}{l}\text { * Can be difficult to create and requires a level of } \\
\text { technological competence }\end{array}$ \\
\hline * Easy to update, adapt and change & $\begin{array}{l}\text { Lacks virtual in the true sense of immersion in } \\
\text { the digital environment }\end{array}$ \\
\hline * No real limitations on size or scope & $\begin{array}{l}\text { Still hindered by lack of technology i.e. } \\
\text { computing power/virtual reality }\end{array}$ \\
\hline $\begin{array}{l}\text { Helps develop skills for students before going } \\
\text { on real fieldwork }\end{array}$ & $\begin{array}{l}\text { * Students can get lost and disorientated in the } \\
\text { virtual world }\end{array}$ \\
\hline \multicolumn{2}{|l|}{$\begin{array}{l}\text { Provide inclusivity benefits to disabled and } \\
\text { disadvantaged students }\end{array}$} \\
\hline \multicolumn{2}{|l|}{ * Can replicate seasonal change of a landscape } \\
\hline $\begin{array}{l}\text { Allows a student to revisit over and over again } \\
\text { unlike a one of real field trip } \\
\text { Allows students to develop skills in a controlled } \\
\text { environment }\end{array}$ & \\
\hline
\end{tabular}


sites can be studied within the time frame of the field trip (Fuller \& France, 2014). This method is particularly useful for VFGs as digital field note books can be created within the VFG and then used and added to when on real fieldwork through for example, tablet computers.

There are not only benefits to physical geoscience with technology, but also the human side of the dicipline to. Questionnaire design, collection and analysis is a staple practice of any geoscience undergraudate degree (McGuirk \& O'Neill, 2005). This can now be succesfully completed online, negating the need for a student to physically complete the questionnaire and further reduces any cost of creating the materials (Clifford, Cope, French, \& Gillespie, 2016). With the advent of computer conference calls, such as Skype, students can now conduct interviews with anyone, anywhere in the world, increasing their scope for research and understanding (Deakin \& Wakefield, 2013). Software advancements and development have aided students and tutors pre and post fieldwork. One of the biggest advancements in software has been the creation of Google Earth. Google Earth is a web based simulation of the Earth, composing of satellite images and aerial photogrammetry which allow the student to explore specific sites in high detail over a period of time (Google Earth, 2016). Google Earth has continued to develop and be improved, and is now a key element of most virtual field trips (De Paor \& Whitmeyer, 2011; Fearnley \& Bunting, 2011; Krakowka, 2012; Kingston et al., 2012; Whitmeyer, 2012). There has been an abundance of new educational applications and software for students to use on both the desktop computer and their mobile devices. From the technical such as ArcMap and GIS software, to more basic online tools such as Digimap and Ordinance Survey maps (Spronken-Smith, McLean, Smith, Bond, Jenkins, et al., 2016).

\section{Future implications of virtual reality for VFGs}

Such advancements and usability will increase the effectiveness of VFGs and we will see the virtual field guides moving closer in alignment to traditional field trips. This narrowing gap between the real and the virtual world will increase when technology for moving around a virtual environment becomes more main stream in the next few years. Virtual reality is one way in which this gap is narrowing. Virtual reality is a digital or computer generated recreation of the real world, often created by complex software to give a computer generated 3 dimensional view of that location (Lindsay, 2015). Virtual reality has seen many forms and is most noted in education for the application second life, for which some educators have tried to develop and utilise in their teaching and learning (Warburton, 2009).

In light of this, for a virtual field guide to become a true virtual fieldtrip, it must incorporate a true virtual reality world with elements of virtual reality (VR) and this is where this new technology is helping (Kamarainen et al., 2013). This is changing with the reduction of size, cost, and innovation surrounding VR technologies (Getchell et al., 2010). Today, VR technologies can be accessed by the general public and can be bought such as OCULUS RIFT and TOUCH (https://www.oculus.com) a high end VR headset for around the same price of today's latest smartphone ( $£ 548$ as of September 2016) or a much cheaper and rudimentary version, Google cardboard for $£ 20$ (https://vr.google.com/cardboard/).

A report by Ericsson Consumer Insight Summary Report states that VR will become one of the fastest developing sectors in the technology industry and is one of the top 
ten consumer trends in 2016 (Ericsson Consumerlab, 2015). This is an important development for VFG's if they do so wish to become more virtual in their design. This development is already beginning to take place with early reports indicating great potential for students in fieldtrips (Brown \& Green, 2016). Google who have created the very accessible and cheap Google Cardboard (RRP £20) have also developed an expeditions package for tutor led VR field trips (Howard, 2016). The main benefit of this new, cheaper and more accessible VR is the use in not only the virtual field trip but also on real field trips. VR headsets allow the user to be mobile in an environment and not tied down to traditional VR which is often linked to a fixed desktop computer (Luckin \& Stanton-Fraser, 2011). Such mobile realities means that learning both formally and informally can take place outside of the classroom and can serve as a link between the two, perfect for fieldwork teachings (Fitzgerald et al., 2013).

While this technology increases all the time the future for VFGs looks bright as technology begins to finally catch up with the idea of a fully virtual and immersive digital field trip. Moving forward and looking at the future of VFGs, there has not been and doesn't seem to be any standardisation of virtual field guides at present. This lack of standardisation is however a strength and a weakness. The strength of this lack of standardisation is that it allows the creators to tailor their guide to their specific needs, allowing much greater flexibility. However, too much flexibility and lack of standardisation such as scale can overwhelm creators and may pose a challenge to new creators with a lack of established templates and guides. While no standardising of VFG content and style exists, there are common themes that have emerged from VFGs. They often have an overview with a smaller spatial scale, followed by a more detailed and in-depth larger spatial scaled VFG. Within this larger spatial scale there is often access to data such as photographs and videos.

\section{Conclusion}

VFG have their place in geoscience teaching despite their challenges in creation as they have many benefits to students and educators. Litherland and Stott (2012) concluded that VFGs should not replace field trips but it is suggested that VFG's work best in a pedagogic sense when they are employed as a tool for students to use the data presented in them to support traditional field trips.

As shown, future technology is improving at a rapid pace and with this new technology and computing power could give new immersive life to the virtual field guide. New research is emerging around the use of augmented and virtual realities in the classroom and virtual field guides, along with using Unmanned Aerial Vehicles to create 3D models for students to explore in this virtual world. The nature of fieldwork is rapidly changing due to new technologies in education and the continued financial pressures placed on departments will continue to drive the development and integration of VFGs in the classroom. The gap between the virtual and real world in terms of realism and accuracy is rapidly diminishing and at some point in the near future, those lines will start to become blurred. VFG therefore can provide an alternative tool to compliment current fieldwork exercises to make sure students develop their learning and skills when on real fieldwork and will continue to do so for some time. 


\section{Acknowledgements}

The author would like to thank Dr. Fran Tracy and Professor Tim Stott for their continued support throughout this PhD and for their encouragement of this paper.

\section{Funding}

N/A.

\section{Availability of data and materials}

N/A.

\section{Authors' information}

ADC is a first year PhD student at Liverpool John Moores University, studying the pedagogical benefits of using unmanned aerial vehicles in geoscience fieldwork education. ADC will be using UAVs to create highly detailed 3D models of field sites that students in geoscience disciplines in LJMU will go on as part of their studies. ADC will place these models into Virtual Field Guides to assess if there is a benefit to the students learning, either pre, post or during fieldwork and will further research into the effectiveness of virtual field guides in higher education with this new technology. This current paper is part of his thorough literature review into the role virtual field guides play in geoscience higher education today.

\section{Ethics approval and consent to participate}

Not needed, however all research is approved by the Liverpool John Moores Ethics committee.

\section{Consent for publication}

Approved.

\section{Competing interests}

The author declares that he has no competing interests.

\section{Publisher's Note}

Springer Nature remains neutral with regard to jurisdictional claims in published maps and institutional affiliations.

Received: 22 March 2017 Accepted: 20 June 2017

Published online: 09 October 2017

\section{References}

Andrews J. R., Kneale P., Sougnez Y. G., Stewart M. T., \& Stott T. M. (2003). Carrying out pedagogic research into the constructive alignment of fieldwork. Planet Special Edition, 5, 51-52.

Arrowsmith C., Counihan A., \& McGreevy D. (2005). Development of a multi-scaled virtual field trip for the teaching and learning of geospatial science. International Journal of Education and Development using ICT, 1(3).

Atchison C. L., \& Feig A. D. (2011). Theoretical perspectives on constructing experience through alternative field-based learning environments for students with mobility impairments. Qualitative Inquiry in Geoscience Education Research, 44(2), 11-21.

Baggott la Velle L. (2005). Virtual field trips. Journal of Biological Education, 39(4), 189

Bellan J. M., \& Scheurman G. (1998). Actual and virtual reality: Making the most of field trips. Social Education, 62, 35-40. Bertol D., \& Foell D. (1997). Designing digital space: An architect's guide to virtual reality. London: Wiley.

Bowman H., Van Den Hoof B., Van De Wijngaert L., \& Van Dijk J. (2005). Information and Communication Technology in Organizations. London: Sage.

Biggs J. (2003). Teaching for quality learning at university (2nd ed., ). Buckingham: Society for Research in Higher Education.

Brown A., \& Green T. (2016). Virtual reality: Low-cost tools and resources for the classroom. TechTrends, 60, 517-519.

Calder S. (2003). No frills: The truth behind the low-cost revolution in the skies (). London: Virgin Books.

Carmichael, P., \& Tscholl, M. (2011). Cases, simulacra and semantic web technologies. Journal of Computer Assisted Learning.

Chen C. C., \& Huang T. C. (2012). Learning in a u-museum: Developing a context-aware ubiquitous learning environment. Computers \& Education, 59(3), 873-883.

Clifford N., Cope M., French S., \& Gillespie T. (Eds.) (2016). Key methods in geography (). Sage.

De Paor D. G., \& Whitmeyer S. J. (2009). Innovation and obsolescence in geoscience field courses: Past experiences and proposals for the future. Geological Society of America Special papers, 461, 45-56.

De Paor D. G., \& Whitmeyer S. J. (2011). Geological and geophysical modeling on virtual globes using KML, COLLADA, and Javascript. Computers \& Geosciences, 37(1), 100-110.

Deakin H., \& Wakefield K. (2013). Skype interviewing: Reflections of two PhD researchers. Qualitative Research, 1468794113488126.

Dunphy A., \& Spellman G. (2009). Geography fieldwork, fieldwork value and learning styles. International Research in Geographical and Environmental Education, 18(1), 19-28.

Dykes J. (2000). An approach to virtual environments for visualization using linked geo-referenced panoramic imagery. Computers, Environment and Urban Systems, 24(2), 127-152.

Ericsson Consumerlab. (2015). 10 hot consumer trends 2016. Retrieved September 1, 2016, from Ericsson Consumerlab: http://www.ericsson.com/res/docs/2015/consumerlab/ericsson-consumerlab-10-hot-consumer-trends-2016-report.pdf 
Eusden J. D., Duvall M., \& Bryant M. (2012). Google earth mashup of the geology in the presidential range, New Hampshire: Linking real and virtual field trips for an introductory geology class. Geological Society of America Special Papers, 492, 355-366.

Falk J., Martin W., \& Balling J. (1978). The novel field trip phenomenon: Adjustment to novel settings interferes with task learning. Journal of Research in Science Teaching, 15(2), 127-134.

Fearnley C., \& Bunting P. (2011). Understanding the potential new roles for mobile computertechnologies for teaching geography fieldwork: Using GIS and social networking to enhance learning opportunities. Enhancing Fieldwork Learning Showcase Event, 2011.

Fitzgerald E., Ferguson R., Adams A., Gaved M., Mor Y., \& Rhodri T. (2013). Augmented reality and mobile learning: the state of the art. International Journal of Mobile and blended learning, 5(4), 43-58.

Fletcher S., \& Dodds W. (2004). Dipping toes in the water: An international survey of residential fieldwork within ICM degree course curricula. Littoral 2004: 7th international symposium: Delivering sustainable coasts: Connecting science and policy (vol. 1, pp. 305-309). Cambridge: Cambridge Press.

Fletcher S., France D., Moore K., \& Robinson G. (2007). Putting technology into fieldwork education: A pedagogic evaluation. Journal of Geography in Higher Education, 31(2), 319-330.

Forman R. T. (2014). Land mosaics: The ecology of landscapes and regions. In F. O. Ndubisi (Ed.), The ecological design and planning reader (pp. 217-234). Washington: Island Press.

France D., Whalley B. W., Mauchline A., Powell V., Welsh K., Lerczak A., ... Bednarz R. (2016). Enhancing fieldwork learning using mobile technologies (Vol. Springer briefs in ecology) (). London: Springer.

Fuller I., Edmondson S., France D., Higgitt D., \& Ratinen I. (2006). International perspectives on the effectiveness of geography fieldwork for learning. Journal of Geography in Higher Education, 30(1).

Fuller I. C. (2012). Taking students outdoors to learn in high places. Area, 44, 7-13.

Fuller I. C., \& France D. (2014). Fieldwork going digital. Geomorphological fieldwork, developments in earth surface processes, 18, 117-128

Fuller I. C., Gaskin S., \& Scott I. (2003). Students perceptions of geography and environmental science fieldwork in the light of restricted access to the field, caused by foot and mouth disease in the UK in 2001. Journal of Geography in Higher Education, 27(1), 79-102.

Gardiner V., \& Unwin D. (1986). Computers and the field class. Journal of Geography in Higher Education, 10, 169-179.

Garner L. C., \& Gallo M. A. (2005). Field trips and their effect on student achievement and attitudes: A comparison of physical versus virtual field trips to the Indian River lagoon. Journal of College Science Teaching, 34(5), 14

Garrison R. D. (2011). E-learning in the 21st century: A framework for research and practice (). Oxon: Routledge.

Garver J. I. (1992). A field-based course in stratigraphy and sedimentology. Journal of Geological Education, 40, 119-124.

Getchell K., Miller A., Nicoll J. R., Sweetman R., \& Allison C. (2010). Games methodologies and immersive environments for virtual fieldwork. IEEE Transactions on Learning Technologies, 3(4), 281-293.

Gilmour, I. (1997). Skiddaw virtual field trip. A study of thermal metamorphism. Retrieved from http://ns2.ijmg.com/ virtual-field-trips-preview.asp?id=188484

Google. (2016). Google earth. Retrieved September 15, 2016, from Google: https://www.google.co.uk/earth/

Hall T., Healey M., \& Harrison M. (2002). Fieldwork and disabled students: Discourses of exclusion and inclusion. ransactions of the Institute of British Geographers, 27(2), 213-231.

Hall T., Healey M., \& Harrison M. (2004). Reflections on 'fieldwork and disabled students: Discourses of exclusion and inclusion. Journal of Geography in Higher Education, 28, 255-280.

Howard N. (2016). Come along and ride on a google expeditions. Retrieved September 1, 2016, from Edutopia: http://www.edutopia.org/blog/ride-on-a-google-expedition-nicol-howard

Hurst S. D. (1998). Use of "virtual" field trips in teaching introductory geology. Computers \& Geosciences, 24(7), 653-658.

Israel A. L. (2012). Putting geography education into place: What geography educators can learn from place-based education, and vice versa. Journal of Geography, 111(2), 76-81.

Jacobson A. R., Militello R., \& Baveye P. C. (2009). Development of computer-assisted virtual field trips to support multidisciplinary learning. Computers \& Education, 52(3), 571-580.

Jarvis C. H., \& Dickie J. (2010). Podcasts in support of experiential field learning. Journal of Geography in Higher Education, 34, 173-186.

Jones R. R., McCaffrey K. J., Clegg P., Wilson R. W., Holliman N. S., Holdsworth R. E., et al. (2009). Integration of regional to outcrop digital data: 3D visualisation of multi-scale geological models. Computers \& Geosciences, 35(1), 4-18.

Kaplan A., \& Haenlein M. (2010). Users of the world, unite! The challenges and opportunities of social media. Business Horizons, 53(1), 59-68.

Kamarainen A. M., Metcalf S., Gotzer T., Browne A., Mazzuca D., Tutwiler M. S., \& Dede C. (2013). EcoMOBILE: Integrating augmented reality and probeware with environmental education field trips. Computers \& Education, 68, 545-556.

Kent M., Gilbertson D., \& Hunt C. (1997). Fieldwork in geography teaching: a critical review of the literature and approaches. Journal of Geography in Higher Education, 21(3), 313-332.

Killerman W. (1996). Biology education in Germany: Research into the effectiveness of different teaching methods. International Journal of Science Education, 18, 333-346.

King N. C. (2011). Engaging students in practical work through new technologies. UK Centre forBioscience Bulletin, 33, 6.

Kingston D. G., Eastwood W. J., Jones P. I., Johnson R., Marshall S., \& Hannah D. M. (2012). Experiences of using mobile technologies and virtual field tours in physical geography: Implications for hydrology education. Hydrology and Earth System Sciences, 16(5), 1281-1286.

Klemm E. B., \& Tuthill G. (2003). Virtual field trips: Best practices. International Journal of Instructional Media, 30(2), 177. Kneale P. E. (2014). Study skills for geography students: A practical guide (2nd ed.).). New York: Routledge.

Krakowka A. (2012). Field trips as valuable learning experiences in geography courses. Journal of Geography, 111(6), 236-244.

Leydon J., \& Turner S. (2013). The challenges and rewards of introducing field trips into a large introductory geography class. Journal of Geography, 112(6), 248-261.

Litherland K., \& Stott T. A. (2012). Virtual field sites: Losses and gains in authenticity with semantic technologies. Technology, Pedagogy and Education, 21(2), 213-230. 
Lindsay S. (2015). Virtual Reality vs. Augmented Reality. Retrieved from AUGMENT: http://www.augment.com/blog/ virtualreality-vs-augmented-reality/

Lonergran N., \& Andres L. W. (1988). Field-based education: Some theoretical considerations. Higher Education Research and Development, 7, 63-77.

Luckin R., \& Stanton-Fraser D. (2011). Limitless or pointless? An evaluation of augumented reality technology in the school and home. International Journal of Technology Enhanced Learning, 3(5), 510-524.

Martin F., \& Ertzberger J. (2013). Here and now mobile learning: An experimental study on the use of mobile technology. Computers \& Education, 68, 76-85.

Marvelf A., Simm D., Schaaf R., \& Harpe R. (2013). Students as scholars: evaluating student-led learning and teaching during fieldwork. Joumal of Geography in Higher Education, 34(4), 547-566.

McCaffrey K. W., Jones R. R., Holdsworth R. E., Wilson R. W., Clegg P., Imber J., et al. (2005). Unlocking the spatial dimension: Digital technologies and the future of geoscience fieldwork. Journal of the Geological Society, 162(6), 927-938.

McElroy B. (1981). Models and reality: Integrating practical work and fieldwork in geography. The Geography Teacher's Guide to the classroom, 95-103.

McGuirk P. M., \& O'Neill P. (2005). Using questionnaires in qualitative human geography. In I. Hay (Ed.), Qualitative research methods in human geography (pp. 147-162). South Melbourne: Oxford University Press.

McMorrow J. (2005). Using a web-based resource to prepare students for fieldwork: Evaluating the dark peak virtual tour. Journal of Geography in Higher Education, 29(2), 223-240.

Medzini A., Meishar-Tal H., \& Sneh Y. (2015). Use of mobile technologies as support tools for geography field trips. International Research in Geographical and Environmental Education, 24(1), 13-23.

Pringle J. K., Westerman R., \& Gardiner A. R. (2004). Virtual geological outcrops-fieldwork and analysis made less exhaustive? Geology Today, 20(2), 64-69.

Ramasundaram V., Grunwald S., Mangeot A., Comerford N. B., \& Bliss C. M. (2005). Development of an environmental virtual field laboratory. Computers \& Education, 45(1), 21-34.

Rawlings D. (1981). Local issues and Enquirey-based learning. Geography 6-19, occasional paper no. 2 (). London: University of London.

Robinson R. (1998). Development issues: Sympathy and paternalism, empathy and realism. In R. Gerber, \& J. Lidstone (Eds.), Developing skills in geographical education (pp. 152-155). Brisbane: Jacaranda Press.

Rose G. (1993). Feminism and geography: The limits of geographical knowledge (). Cambridge: Polity Press.

Royal Geographical Association. (2016). Geography in the UK. Retrieved September 6, 2016, from Royal Geographical Association: http://www.rgs.org/GeographyToday/Geography+in+the+UK.htm

Rozell E., \& Garner W. (2000). Cognitive, motivation and affective processes associated with computer-related performance: A path analysis. Computers in Human Behaviour, 16(2), 199-222.

Seale J. (2013). E-learning and disability in higher education: Accessibility research and practice (). Abingdon: Routledge.

Simm D. J., \& David C. A. (2002). Effective teaching of research design in physical geography. Journal of Geography in Higher Education, 26(2), 169-180.

Slater T. R. (1993). Locality-based studies and the Enterprise initiative. Journal of Geography in Higher Education, 17, 47-55.

Spicer J. l., \& Stratford J. (2001). Student perceptions of a virtual field trip to replace a real field trip. Journal of Computer Assisted Learning, 17(4), 345-354.

Spronken-Smith R., McLean A., Smith N., Bond C., Jenkins M., Marshall S., et al. (2016). A toolkit to implement graduate attributes in geography curricula. Journal of Geography in Higher Education, 40(2), 254-266.

Stainfield J., Fisher P., Ford B., \& Solem M. (2000). International virtual field trips: A new direction? Journal of Geography in Higher Education, 24(2), 255-262.

Stoddard J. (2009). Toward a virtual field trip model for the social studies. Contempory Issues Technology Teacher Education, 9(4), 421-438.

Stokes A., Collins T., Maskall J., Lea J., Lunt P., \& Davies S. (2012). Enabling remote access to fieldwork: Gaining insight into the pedagogic effectiveness of 'direct' and 'remote' field activities. Journal of Geography in Higher Education, 36(2), 197-222.

Stott, T., Litherland, K., Carmichael, P., \& Nuttall, A. (2014). Using interactive virtual field guides and linked data in Geoscience teaching and learning. In V. Tong, \& V. Tong, Geoscience research and innovation (innovation in science education and technology ed), Vol. 20, 163-188). Dordrecht : Springer Science and Business Media.

Stott T., Nuttall A., \& McCloskey J. (2009). Design, development and student evaluation of a virtual alps field guide. Planet, 22(1), 64-71.

Stott T. A., Nuttall A., Eden N., Smith K., \& Maxwell D. (2008). Suspended sediment dynamics in the Morteratsch proglacial zone, Bernina alps, Switzerland. Geografi ska Annaler Series A: Physical Geography, 90(4), 299-313.

Ternan J. L., Charlkley B. S., \& Elmes A. (1999). Long haul field courses: Lessons from the Plymouth experience working paper no. 4. Plymouth. University of Plymouth: SEED Publications.

Tuthill G., \& Klemm E. B. (2002). Virtual field trips: Alternatives to actual field trips. International Journal of Instructional Media, 29(4), 453-468.

UK GOV. (2016). Expanding private higher education: Key issues for the 2015 parliament. Retrieved September 6, 2016, from UK Parliment: https://www.parliament.uk/business/publications/research/key-issues-parliament-2015/ education/higher-education/

Wall G. P., \& Speake J. (2012). European geography higher education fieldwork and the skills agenda. Journal of Geography in Higher Education, 36(3), 421-435.

Warburton J., \& Higgitt M. (1997). Improving the preparation for fieldwork with 'IT': Two examples from physical geography. Journal of Geography in Higher Education, 21, 333.

Warburton S. (2009). Second Life in higher education: Assessing the potential for and the barriers to deploying virtual worlds in learning and teaching. British Journal of Educational Technology, 40(3), 414-426.

Welsh K., \& France D. (2012). Spotlight on... Smartphones and fieldwork. Geography, 97, 47.

Welsh K. E., Mauchline A. L., Park J. R., Whalley W. B., \& France D. (2013). Enhancing fieldwork learning with technology: practitioner's perspectives. Journal of Geography in Higher Education, 37(3), 399-415. 
Wentzel P. (2005). Using Mobile Technology to Enhance Students' Educational Experiences. ECAR case study, 2, case study from the EDUCAUSE Center for Applied Research. Colorado. EDUCAUSE Centre.

Whalley B. W., France D., Park J. R., Mauchline A. L., Powell V., \& Welsh K. (2015). iPad use in fieldwork: Formal and informal use to enhance pedagogical practice in a bring your own technology world. In N. Souleles, \& C. Pillar (Eds.), iPad use in fieldwork: Proceedings of the 1st international conference on the use of iPads in higher education (ihe2014) (pp. 110-125). Cambridge: Cambridge Scholars Publishing.

Whitmeyer S. J. (Ed.) (2012). Google earth and virtual visualizations in geoscience education and research (vol. 492). Colorado. Geological Society of America.

Submit your manuscript to a SpringerOpen ${ }^{\circ}$ journal and benefit from:

- Convenient online submission

- Rigorous peer review

Open access: articles freely available online

High visibility within the field

Retaining the copyright to your article

Submit your next manuscript at $\gg$ springeropen.com 